\title{
LIGHTWEIGHT AGGREGATE CONCRETE: EFFECT OF AGE AND CURING METHOD
}

Rita Nemes ${ }^{1}$

УДК: 666.972 .125

DOI:10.14415/zbornikGFS26.04

Summary: For normal weight concrete we have conversion factors, when testing not at the age of 28 days or the curing of specimens is not according to the standard. Lightweight aggregate concrete may be very different from normal weight concrete from this point of view. The properties mainly depend on the properties of the lightweight aggregate like particle density, water absorption capacity. The aim is to study the impact of the time under water storage on compressive strength and fracture tests results.

Keywords: Lightweight aggregate concrete (LWAC), standard cube test, under water storage, age effect

\section{INTRODUCTION}

According to the current standard of concrete (EN 206-1) [1] the strength for classification is at the age of 28 days, following a wet curing (kept in a space having a relative humidity of $100 \%$ ). The standards also change over time and may be different from country to country. The earlier applied mixed curing (up to 7 days in water and then till age 28 days in laboratory air), in the Hungarian standard is still allowed and common in engineering practice. The real curing of a newly constructed reinforce concrete structure (which is rather close to the mixed curing) is also very different from the standardised European method. An examination of an existing structure is possible only by drilled core samples, specimens often having only 50 or $100 \mathrm{~mm}$ nominal diameter in case of dense reinforcement.

In the case of normal weight concrete (NWC) lots of data, experimental results were gathered over the years. Conversion factors may be found in several standards, but the lightweight aggregate concrete (LWAC) is different. Density, elasticity, hardening rate and water absorption properties of LWAC may be very different from NWC. They mainly depend on the properties of lightweight aggregate (LWA) like: particle density, water absorption capacity, surface coating, crushing resistance etc. The amount and distribution of LWA in the concrete matrix is also important. In the sign of concrete the compressive strength class is given already for two different sample shapes. (Table 1) (Table EN 206-7) Such a table is included in the lightweight concrete standard as well, but it contains different numerical values. (Table 2) (Table EN 206-8) The characteristic

\footnotetext{
${ }^{1}$ Rita NEMES, PhD, assistant professor at the Budapest University of Technology and Economics, Department of Construction Materials and Engineering Geology, Müegyetem rkp. 3. H-1111 Budapest tel: +36 14633454 e-mail: nemes.rita@epito.bme.hu
} 
strength value, obtained from testing cylindrical or cubic sample is closer to one another. The stiffness of the LWAC is less than of the NWC. The modulus of elasticity of LWAC is defined not only by the compressive strength, but also by the density. This density effect is smaller in case of slimmer specimens, as shown in LWAC grades (Table 2). The ratio of compressive strength and splitting strength is different, too [2]. The LWAs are porous, so have better thermal insulation capacity, and therefore the hardening rate of concrete is faster [3]. The fast hardening helps the internal curing effect due to the typically open pore structure of LWA. These effects are generally favourable in practice, thus neglecting them influences safety in a positive way. The high porosity of LWAC due to the LWA having open pores (and this is usually the case) means an increased water absorbing capability compared to NWA. The effect of this however is that the wet curing method will influence more the measurable compressive strength result but in a negative direction. Although a good hydration causes higher strength, but less strength can be measured in wet conditions. Therefore, the standard ratio for under water and mixed storage does not give realistic result for LWAC. An even more specific situation is, if the compressive test is carried out not exactly at the age of 28 days.

Table 1 Compressive strength class for NWC (EN206-1 Table 7)

\begin{tabular}{|c|c|c|}
\hline $\begin{array}{c}\text { Comp. } \\
\text { strength } \\
\text { class }\end{array}$ & $\begin{array}{c}\text { Min. } \\
\text { character- } \\
\text { ristic } \\
\text { cylinder } \\
\text { strength } \\
\mathrm{f}_{\text {ck,cyl }} \\
{[\mathrm{MPa}]}\end{array}$ & $\begin{array}{c}\text { Min. } \\
\text { character- } \\
\text { ristic cube } \\
\text { strength } \\
\mathrm{f}_{\text {ck,cube }} \\
{[\mathrm{MPa}]}\end{array}$ \\
\hline $\mathrm{C} 8 / 10$ & 8 & 10 \\
\hline $\mathrm{C} 12 / 15$ & 12 & 15 \\
\hline $\mathrm{C} 16 / 20$ & 16 & 20 \\
\hline $\mathrm{C} 20 / 25$ & 20 & 25 \\
\hline $\mathrm{C} 25 / 30$ & 25 & 30 \\
\hline $\mathrm{C} 30 / 37$ & 30 & 37 \\
\hline $\mathrm{C} 35 / 45$ & 35 & 45 \\
\hline $\mathrm{C} 40 / 50$ & 40 & 50 \\
\hline $\mathrm{C} 45 / 55$ & 45 & 55 \\
\hline $\mathrm{C} 50 / 60$ & 50 & 60 \\
\hline $\mathrm{C} 55 / 67$ & 55 & 67 \\
\hline $\mathrm{C} 60 / 75$ & 60 & 75 \\
\hline $\mathrm{C} 70 / 85$ & 70 & 85 \\
\hline $\mathrm{C} 80 / 95$ & 80 & 95 \\
\hline $\mathrm{C} 90 / 105$ & 90 & 105 \\
\hline $\mathrm{C} 100 / 115$ & 100 & 115 \\
\hline
\end{tabular}

Table 2 Compressive strength class for LWAC (EN206-1 Table 8)

\begin{tabular}{|c|c|c|}
\hline $\begin{array}{c}\text { Comp. } \\
\text { strength } \\
\text { class }\end{array}$ & $\begin{array}{c}\text { Min. } \\
\text { character- } \\
\text { ristic } \\
\text { cylinder } \\
\text { strength } \\
\mathrm{f}_{\text {ck,cyl }}[\mathrm{MPa}]\end{array}$ & $\begin{array}{c}\text { Min. } \\
\text { character- } \\
\text { ristic cube } \\
\text { strength } \\
\mathrm{f}_{\text {ck,cube }}[\mathrm{MPa}]\end{array}$ \\
\hline LC8/9 & 8 & 9 \\
\hline LC12/13 & 12 & 13 \\
\hline LC16/18 & 16 & 18 \\
\hline LC20/22 & 20 & 22 \\
\hline LC25/28 & 25 & 28 \\
\hline LC30/33 & 30 & 33 \\
\hline LC35/38 & 35 & 38 \\
\hline LC40/44 & 40 & 44 \\
\hline LC45/50 & 45 & 50 \\
\hline LC50/55 & 50 & 55 \\
\hline LC55/60 & 55 & 60 \\
\hline LC60/66 & 60 & 66 \\
\hline LC70/77 & 70 & 77 \\
\hline LC80/88 & 80 & 88 \\
\hline & & \\
\hline
\end{tabular}

The aim is studying the impact on the compressive strength and fracture tests results of time and under water storage. 


\section{EXPERIMENTAL STUDIES}

\subsection{CONCRETE MIXTURES}

We studied four different LWAC mixtures (with different aggregates, and different strength grades) compared to a reference, normal concrete (Table 3). The cement type and content (CEM I $\left.42.5 \mathrm{~N}, 350 \mathrm{~kg} / \mathrm{m}^{3}\right)$ and the water-cement ratio $(\mathrm{w} / \mathrm{c}=0.43)$ was kept constant, so the cement stone was uniform is all cases. The concrete mixes differ only in the added aggregate. We used different LWA types, and quantities. The grading curve and the rate of normal weight aggregate (NWA) was different to give good workability and enough strength.

Table 3 Measured mixes (aggregate type, strength grade and density of concrete)

\begin{tabular}{|c|c|c|c|}
\hline $\begin{array}{c}\text { Marking of } \\
\text { mix }\end{array}$ & Aggregate name & Planned strength grade & $\begin{array}{c}\text { Planned density of concrete } \\
{\left[\mathrm{kg} / \mathrm{m}^{3}\right]}\end{array}$ \\
\hline $\mathrm{R}$ & $\begin{array}{c}\text { sandy gravel } \\
\text { aggregate } \\
\text { (reference) }\end{array}$ & C35/45 & 2360 \\
\hline L & Liapor & LC30/33 & 1900 \\
\hline G & Geofil-N & LC25/28 & 1930 \\
\hline LL & $\begin{array}{c}\text { Liapor }+ \\
\text { Liasand }\end{array}$ & LC20/22 & 1430 \\
\hline P & Poraver & LC8/9 & 1660 \\
\hline
\end{tabular}

The material of the LWAs were expanded clay and expanded glass (Table 4). Aggregate for LWAC is most commonly expanded clay. Typically, in load-bearing LWACs only for the bigger fractions is LWA used instead of gravel $(>4 \mathrm{~mm})$ like the Liapor products, but in case of lower load bearing capacity requirement it is possible to use LWA in the sand fraction (Liasand) too. The most readily available LWAs in Europe are the Liapor products. Most of the literature data for LWAC is available for expanded clay aggregate. An other choice for artificial expanded LWA is expanded glass. Most expanded glass aggregates have low density and high water absorption capacity (e.g. Poraver products), but there exist expanded glass LWA with low water absorption ( $<10 \%$ by mass) (e.g. Geofil products). The aggregate particles are very porous, but the surface is closed, this causes the low water absorption. Both expanded glass products have the great advantage of producing them from waste, the energy demand out of the production is smaller, than in case of expanded clay pellets.

The LWAs are mixed only with water before concrete mixing. Due to the high water absorption is necessary a premixing with $50 \%$ of the one-hour-water absorption quantity of water. The other $50 \%$ was added to the mixing water. Thus, the LWAs were saturated and the water-cement ratio of cement paste was kept constant. 
Table 4 Characteristics of aggregates

\begin{tabular}{|c|c|c|c|c|c|}
\hline Name & Material & $\begin{array}{c}\text { Particle } \\
\text { density } \\
{[\mathrm{g} / \mathrm{ml}]}\end{array}$ & $\begin{array}{c}\text { Water } \\
\text { absorption } \\
{[\% \text { by mass }]}\end{array}$ & $\begin{array}{c}\text { Water } \\
\text { absorption } \\
{[\% \text { by volume }}\end{array}$ & $\begin{array}{c}\text { Fraction } \\
{[\mathrm{mm}]}\end{array}$ \\
\hline gravel & $\begin{array}{c}\text { natural } \\
\text { quartz }\end{array}$ & 2.64 & 0 & 0 & $4 / 8$ \\
\hline sand & $\begin{array}{c}\text { natural } \\
\text { quartz }\end{array}$ & 2.64 & 0 & 0 & $0 / 4$ \\
\hline Liapor & $\begin{array}{c}\text { expanded } \\
\text { clay }\end{array}$ & 0.83 & 36 & 30 & $4 / 16$ \\
\hline Liasand & $\begin{array}{c}\text { expanded } \\
\text { clay }\end{array}$ & \multicolumn{2}{|c|}{ could not be measured, } & $0 / 8$ \\
\hline Geofil-N & $\begin{array}{c}\text { expanded } \\
\text { glass }\end{array}$ & 1.14 & 1 & 1.1 & $2 / 10$ \\
\hline Poraver & $\begin{array}{c}\text { expanded } \\
\text { glass }\end{array}$ & 0.3 & 26 & 8 & $4 / 8$ \\
\hline
\end{tabular}

The main difference between the studied mixtures:

$\mathrm{R}$ : reference mixture with natural normal weight aggregate (quartz gravel and sand)

L: a typical load-bearing LWAC with the most common aggregate type

G: a load-bearing LWAC with closed surface porous LWA (a special expanded glass)

LL: LWAC with all fractions out of LWA (without NWA)

P: LWAC with very low strength coarse LWA and natural sand

\subsection{SPECIMENS, CURING METHODS AND AGES}

All measured specimens were standard cubes $(150 \times 150 \times 150 \mathrm{~mm})$. The studied ages were 3, 7, 28 and 91 days. The specimens were cured under water for 3, 7 or 28 days. During the 7 days testing period three specimens were cured for 3 days and three specimens till 7 days under water. During the 28 and 91 days testing period three-three specimens were for 3, 7 and 28 days cured under water. For all cases we prepared threethree specimens (Table 5).

Table 5 Test matrix: specimen storage and test age (and the status in time of the test)

\begin{tabular}{|c|c|c|c|}
\hline $\begin{array}{c}\text { Test age [day] / Under } \\
\text { water storage [day] }\end{array}$ & 3 & 7 & 28 \\
\hline 3 & 3 cubes (wet) & & \\
\hline 7 & 3 cubes (dry) & 3 cubes (wet) & \\
\hline 28 & 3 cubes (dry) & 3 cubes (dry) & 3 cubes (wet) \\
\hline 91 & 3 cubes (dry) & 3 cubes (dry) & 3 cubes (dry) \\
\hline
\end{tabular}




\section{TEST RESULTS}

\subsection{EFFECT OF CURING ON THE HARDENING RATE}

In each tests case, it was found that the hardening rate of LWAC was faster than that of the reference concrete. However depending on the type of the aggregate, the hardening rate was different.

In case the specimens are stored under water (i. e. under the same conditions of hydration and crushing state) and the reference concrete strength (Figure 1) is taken to $100 \%$ we see in each case that the LWAC strength ratio at three days age is the maximum and continuously decreased (Table 6). So the hardening rate of all LWAC was faster than the reference concretes (Table 7).

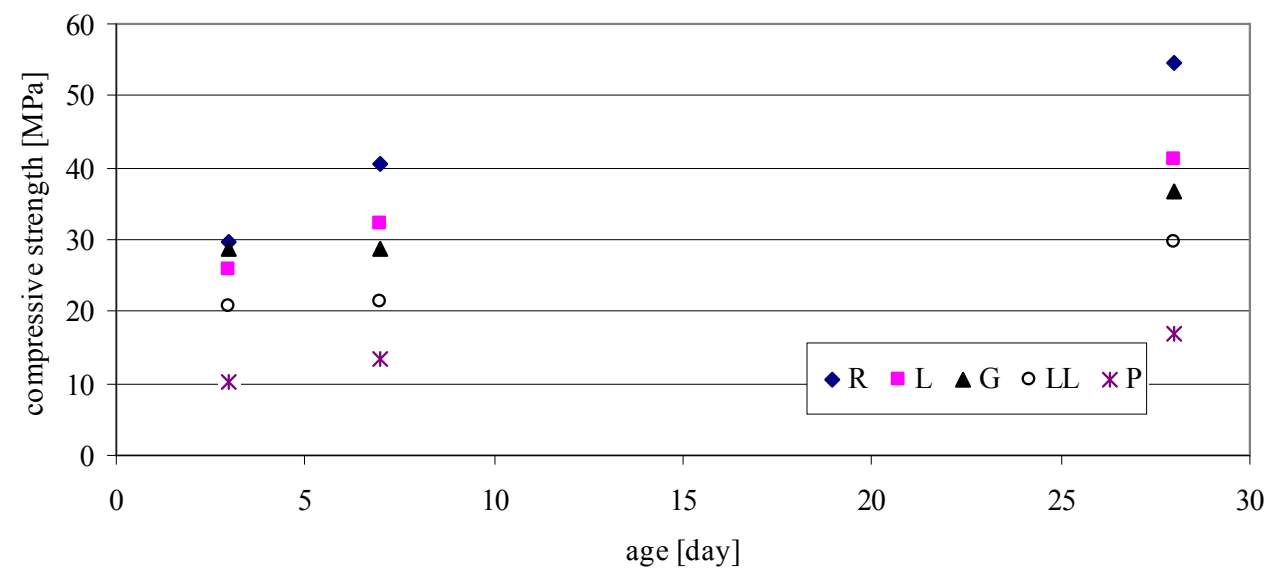

Figure 1 Compressive strength of LWAC and reference concrete in case of under water curing till crushing

Table 6 Strength ratio of the different LWAC to reference concrete (under water stored, "wet cured" specimens)

\begin{tabular}{|c|c|c|c|}
\hline $\begin{array}{c}\text { Mixture / } \\
\text { Age }\end{array}$ & 3 day & 7 day & 28 day \\
\hline R & $100 \%$ & $100 \%$ & $100 \%$ \\
\hline L & $87 \%$ & $80 \%$ & $80 \%$ \\
\hline G & $97 \%$ & $70 \%$ & $67 \%$ \\
\hline LL & $70 \%$ & $53 \%$ & $54 \%$ \\
\hline P & $34 \%$ & $33 \%$ & $31 \%$ \\
\hline
\end{tabular}

Table 7 Hardening rate of the different LWAC (under water stored, "wet cured" specimens)

\begin{tabular}{|c|c|c|c|}
\hline $\begin{array}{c}\text { Mixture } / \\
\text { Age }\end{array}$ & 3 day & 7 day & 28 day \\
\hline R & $54 \%$ & $74 \%$ & $100 \%$ \\
\hline L & $62 \%$ & $78 \%$ & $100 \%$ \\
\hline G & $78 \%$ & $78 \%$ & $100 \%$ \\
\hline LL & $70 \%$ & $72 \%$ & $100 \%$ \\
\hline $\mathrm{P}$ & $60 \%$ & $79 \%$ & $100 \%$ \\
\hline
\end{tabular}


All specimens were already air-dry at the age of 91 days, so the crushing conditions in this case are the same. Thus, the effect of curing (under water storage time) can be observed here.

When using very low particle density and high water absorption LWA $(\mathrm{P})$ or very much LWA (LL) the storage method has no effect. Of course, there should not be a large surface of a structure to dry, early cracks should be avoided, then the curing method has little effect on strength and thus on the classification if it is not the same as the standard method (28 days, wet cured specimen) [4,5]. The reason of this small difference in strength is the large amount of water inside the aggregates, which promotes the hydration of the critical area at the border of the aggregate pellet and mortar matrix. There is other supplementary material in the LWAC, this effect will be stronger [6].

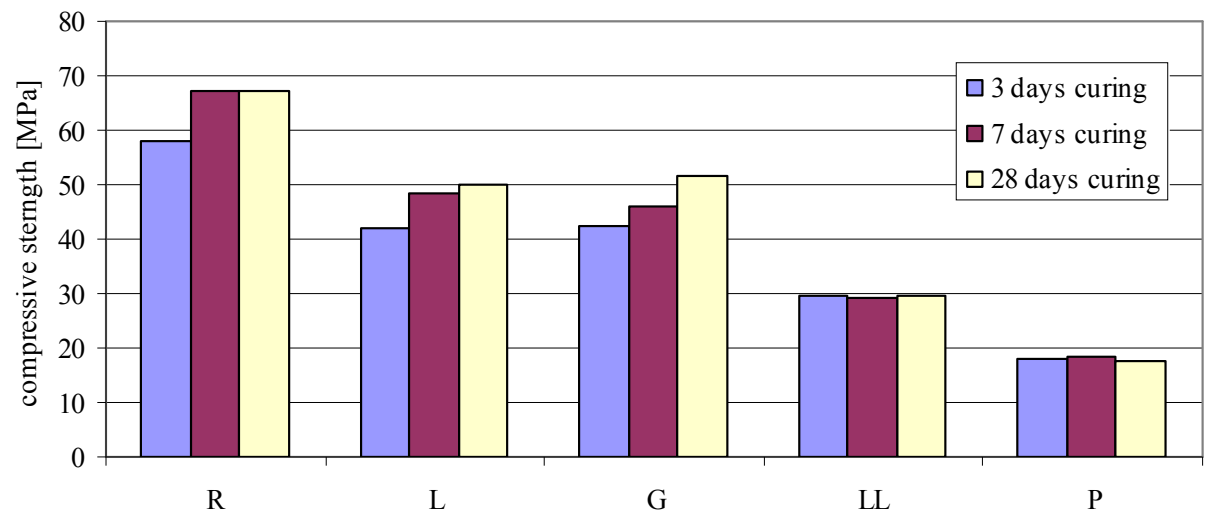

Figure 2 Compressive strength at the age of 91 days following different curing under water

However in contrast, if the LWA has relative high strength (Liapor, Geofil-N), the longer curing has a well detectable positive effect. The strength of reference concrete is decreased by $13 \%$ if the curing is only 3 days, this decreasing in case of mixture $\mathrm{L}$ or $\mathrm{G}$ is $16-18 \%$. After 7 days of wet curing $3-10 \%$ decrease could be observed. So despite the fact that according to the general perception of the curing is less important, but for the structural strength it is even more important. Significant effect of curing explained the faster hardening rate.

\subsection{EFFECT OF THE PHYSICAL STATE OF THE SPECIMENS WHEN CRUSHING}

In 7 days age, two cases were studied: 3 days under water curing followed by laboratory air conditioning, and 7 days under water storage in each cases (the reference and all the lightweight concrete). It was found that the specimens stored in water for 7 days smaller strength was measured then of those, which were stored under water for only 3 days. At this age, the saturation effect of the test sample is greater than the positive difference from the better hydration. At higher strengths range $(\mathrm{R}, \mathrm{L}, \mathrm{G})$ the effect is $6-8 \%$ lower than in the case of the strength of wet curing. It is in the saturated state at high water 
absorption and crushing the additive difference between $11-16 \%$ respectively. This can be explained by the higher water absorption capacity of the specimen.

In case of NWC was measured at 28 days of age a greater strength value. The longer the specimen is stored under water, thus enhancing a good curing (good hydration) the influence on strength is greater than the effect in case of wet specimens. We had identical values in the case of three LWAC storage mode. The effect of increasing strength due to right hydration neutralises the decrease in strength due to the wet state.

\section{CONCLUSION}

The four LWAC were very different (low and high strength, low and high water absorption capability, low and high LWA content) however the 28-day strength was independent on the type of curing (time of under water storage) in all cases. This effect is given in the difference from the strength of the reference concrete (NWC). Thus different curing methods of the LWAC does not make any difference in compressive strength classification of the 28 days old samples. The opposing effects neutralize each other.

This does not mean that there is no positive effect of the good treatment (curing). Compressive strength of reference concrete after only 3-days curing is $10 \%$ lower, than after 28-days curing. The difference of 91-days strength after 7 and 28 days curing is minimal. For NWC 7 days curing can be enough.

By the literature in case of LWAC is an internal curing effect. If the aggregate has low density, and high water absorption capacity (LL, P), there is no measurable difference in the 91 day compressive strength depending on the time period of curing $(3,7$ or 28 days). So here prevails the internal curing effect. This of course, under the condition of high water absorption capability of the aggregate is true, and that these aggregates are really saturated with water, before mixing.

In case of LWAC with high strength and closed aggregate surface (low water absorption capacity) the curing has even greater effect on compressive strength than in the case of NWC. The strength reduction of LWACs was between 15 and $20 \%$ after only 3 days curing, and between 3 and $10 \%$ after only 7 days curing instead of 28 days under water storage.

\section{ACKNOWLEDGEMENTS}

Author wishes to express their gratitude to the Duna-Dráva Cement Kft., Biotech Hungária Kft., Geofil Kft. and Liabau Kft. which companies supported present research and provided the tested materials.

\section{REFERENCES}

[1] EN 206-1:2000 Concrete - Part 1: Specification, performance, production and conformity 
[2] Bogas, J. A.; Nogueira, R.: Tensile strength of structural expanded clay lightweight concrete subjected to different curingconditions KSCE Journal Of Civil Engineering 2014 Vol.: 18 Issue: 6 pp: 1780-1791

[3] Čeh A., Kovač Striko J., Kasaš K.: Konstruktivni laki betoni sa agregatima od recikliranog otpadnog stakla, PhiDAC 2011 -Zbornih radova, Novi Sad, 21-23 Septembar, 2011, pp 391-398

[4] Fenyvesi, O.: Affect of lightweight aggregate to early age cracking in concrete Periodica Polytechnica - Civil Engineering 2011 Vol.: 55 Issue: 1 pp. 63-71

[5] Fenyvesi, O., Nemes, R.: Early age shrinkage cracking in LWAC 6th Central European Congress on Concrete Engineering, CCC 2010: Concrete Structures for Challenging Times. Marianske Lazne, Czech Republic, 2010.09.30-2010.10.01. pp. $79-88$

[6] Rossignolo, J. A.; Agnesini, MVC: Effect of curing condition on properties of polymer-modified lightweight concrete Ed. by: Figueiras, J; Juvanders, L; Faria, $R$ Conference: International Conference Composites in Construction (CCC2001) Porto, Portugal Date Oct. 10-12, 2001 Composites in Construction pp: 67-71 